\title{
Efek Hipoglikemik Ekstrak Cincau Hitam (Mesona palustris BL) pada Tikus Wistar Diabetes yang di Induksi Alloxan
}

\section{Hypoglycemic Effect of Black Grass Jelly (Mesona palustris BL) Extract on Alloxan Induced Diabetic Wistar Rats}

\author{
Tri Dewanti W' ${ }^{1}$, Novita Wijayanti ${ }^{1}$, Dian Handayani ${ }^{2}$, Nia Rochmawati \\ ${ }^{1}$ Program Studi Ilmu dan Teknologi Pangan Jurusan Teknologi Hasil Pertanian Fakultas Teknologi Pertanian \\ Universitas Brawijaya Malang \\ ${ }^{2}$ Laboratorium Gizi Fakultas Kedokteran Universitas Brawijaya Malang
}

\begin{abstract}
ABSTRAK
Cincau hitam atau black grass jelly (Mesona palustris BL) adalah bahan minuman tradisional Indonesia yang dipercaya bermanfaat untuk kesehatan. Cincau hitam biasanya dikonsumsi dalam bentuk gel untuk es campur. Pada penelitian ini cincau hitam dibuat serbuk sehingga praktis penggunaannya. Penelitian dilakukan untuk mengetahui efek hipoglikemik serbuk ekstrak cincau hitam pada tikus Wistar diabetes karena induksi alloxan, dengan rancangan nested design (faktor perlakuan dan waktu) pada kelompok perlakuan dan menggunakan kontrol. Pengukuran dilakukan sesudah perlakuan pada semua kelompok. Terdapat 5 kelompok, kontrol negatif (tikus normal), kontrol positif (tikus diabetes), tikus diabetes perlakuan dengan obat glibenklamid, tikus diabetes perlakuan suplemen cincau hitam dosis 1 (7,2mg/200gBB) dan perlakuan dosis $2(21,6 \mathrm{mg} / 200 \mathrm{gBB})$. Hasil dari penelitian ini serbuk suplemen ekstrak cincau hitam tergolong tinggi aktifitas antioksidannya ( $\left.\mathrm{IC}_{50}=69,04 \pm 2,89 \mathrm{ppm}\right)$. Hasil penelitian menunjukkan suplemen ekstrak cincau hitam mempunyai efek hipoglikemik. Efek hipoglikemik perlakuan suplemen dosis 2 bahkan tidak berbeda dengan perlakuan obat diabetes glibenklamid. Hasil histopatologi dengan pewarnaan HE perlakuan dosis 2 selama 4 minggu menunjukkan secara signifikan dapat memperbaiki kerusakan morfologi pulau Langerhans pankreas karena induksi alloxan. Dapat disimpulkan pemberian serbuk ekstrak cincau hitam pada dosis 21,6mg/200g BB selama 4 minggu dapat memberikan efek hipoglikemik setara dengan glibenklamid, dan memperbaiki kerusakan morfologi pulau Langerhans pankreas pada tikus diabetes yang diinduksi alloxan.
\end{abstract}

Kata Kunci: Efek hipoglikemik, induksi alloxan, pulau Langerhans, serbuk ekstrak cincau hitam (Mesona palustris BL), tikus Wistar diabetes

\begin{abstract}
Black grass jelly (Mesona palustris BL), an Indonesian traditional beverage, is believed to be beneficial to health. Black grass jelly is usually consumed in the form of gels for cold beverages. In this study, black grass jelly is extracted and made into powder for practical use. This study is conducted to find out the hypoglycemic effect of black grass jelly powder extract on diabetic Wistar rats induced alloxan, by using nested design (treatment and time factor) in the treatment group and using controls. Measurements were taken after treatment in all groups. There were 5 groups, namely, negative control (normal rats), positive control (diabetic rats), diabetic rats treated with glibenclamide, diabetic rats treated with black grass jelly supplement dose $1(7,2 \mathrm{mg} / 200 \mathrm{~g} \mathrm{bw})$ and dose $2(21,6 \mathrm{mg} / 200 \mathrm{~g} \mathrm{bw})$. The results of this study shows that black grass jelly extract powder supplement has high antioxidant activity (IC50 =69,04 $\pm 2,89 \mathrm{ppm})$. The results show treatments with black grass jelly extract supplements have hypoglycemic effects. Hypoglycemic effect of treatment dose 2 supplements is not different from the treatment of glibenclamide diabetic drug. The results of histopathology with $H E$ staining that treatment dose 2 for 4 weeks significantly repair the morphology damage of the islets of Langerhans of the pancreas due to alloxan induction. It can be concluded that black grass jelly powder extract administration of $21,6 \mathrm{mg} / 200 \mathrm{~g}$ bw for 4 weeks can provide a hypoglycemic effect equivalent to glibenclamide, and repair the morphology damage of the islets of Langerhans of the pancreas in alloxan induced diabetic rats.
\end{abstract}

Keywords: Alloxan induced, black grass jelly (Mesona palustris BL) extract, diabetic Wistar rats, hypoglycemic effect, islets of Langerhans

Jurnal Kedokteran Brawijaya, Vol. 28, No. 3, Februari 2015; Korespondensi: Tri Dewanti W. Program Studi Ilmu dan Teknologi Pangan Jurusan Teknologi Hasil Pertanian Fakultas Teknologi Pertanian Universitas Brawijaya Malang, Jl. Veteran Malang Tel. (0341) 565845 Email:tridewantiw@ub.ac.id 


\section{PENDAHULUAN}

Diabetes melitus (DM) telah dikategorikan sebagai penyakit global oleh WHO. Jumlah penderita DM di dunia meningkat dari 171 juta jiwa pada tahun 2000 menjadi 366 juta jiwa pada tahun 2030 (1). Menurut data statistik dari studi Global Burden of Disease WHO tahun 2004, Indonesia menempati peringkat pertama di Asia Tenggara, dengan prevalensi penderita DM sebanyak 8.426.000 jiwa di tahun 2000 dan diperkirakan meningkat 2,5 kali lipat pada tahun 2030 (2).

Pada kondisi diabetes melitus didapatkan kadar glukosa dalam darah meningkat (hiperglikemia) akibat tubuh kekurangan insulin atau fungsi insulin tidak lagi efektif (resitensi insulin). Resistensi insulin dapat disebabkan oleh stres oksidatif, yakni ketidakseimbangan antara radikal bebas dan antioksidan. Stres oksidatif dapat mengurangi sensitifitas terhadap insulin sehingga terjadilah resistensi insulin $(3,4)$.

Sejauh ini penggunaan insulin serta obat kimiawi sebagai jalur pengobatan DM, sering memberatkan pasien karena harga sediaan obat kimiawi yang tergolong mahal. Selain itu pengobatan kimia dapat memberikan efek samping seperti mual, diare, hipersekresi asam lambung, vertigo, hipertiroidisme dan lain sebagainya (5). Salah satu perkembangan penanganan DM adalah pemanfaatan herbal yang bersifat antioksidan (6).

Cincau hitam (Mesona palustris BL) merupakan bahan pangan tradisional yang mengandung antioksidan dan secara empiris telah dimanfaatkan untuk kesehatan. Beberapa komponen aktif cincau hitam yang memiliki nilai fungsional di antaranya flavonoid, polifenol, glikosida saponin, terpenoid dan steroid $(7,8)$. Berdasarkan hasil penelitian, ekstrak Hsian-tsao (Mesona procumbens Hemsl), sejenis cincau hitam di China mampu memperbaiki terhadap kerusakan DNA limfosit yang dipapar hidrogen peroksida dan radiasi ultraviolet (9). Cincau hitam mempunyai efek antimutagenik (10), serta protektif terhadap renal (ginjal) pada tikus diabetes (11). Penelitian ekstrak cincau hitam (Mesona palustris BL) Indonesia atau biasa disebut janggelan juga telah dilakukan terbukti bersifat sebagai imunomodulator dan kemopreventif terhadap kanker (12). Cincau hitam secara empiris juga diyakini berkhasiat untuk menurunkan kadar gula darah pada orang yang menderita diabetes (13). Penelitian dilakukan untuk mengetahui efek hipoglikemik suplemen ekstrak cincau hitam terhadap penurunan kadar gula darah pada tikus Wistar diabetes yang diinduksi alloxan.

\section{METODE}

Bahan utama dalam penelitian ini adalah simplisia cincau hitam (Mesona palustris $\mathrm{BL}$ ) yang diperoleh dari petani di daerah Magetan Jawa Timur. Bahan kimia yang digunakan etanol $70 \%$, etanol $96 \%, \mathrm{Na}_{2} \mathrm{CO}_{3}$, Folin Ciocalteau, reagen 1,1-diphenyl-2-pycril-hidrazil (DPPH), alloxan [ 5,6-dioxyuracyl] tetrahydrate [Sigma Co] untuk induksi diabetes, glibenklamid, dan glucose kit (Glucose Oxidase). Hewan yang digunakan pada penelitian ini adalah tikus putih (Rattus norvegicus) jenis Wistar jantan usia 2-3 bulan dengan berat 200-300gram. Bahan untuk pakan tikus mengacu pada American Institute of Nutrition (AIN 1993) yaitu kasein, pati jagung, minyak jagung dan sukrosa, campuran mineral (AIN $93 \mathrm{G}$ ) dan campuran vitamin (AIN $93 \mathrm{VX})$, [ICN, Biomedical ICA, USA] untuk tikus.

Tikus Wistar jantan sebanyak 25 ekor dengan berat 200$300 \mathrm{~g}$ dibagi secara acak menjadi 5 kelompok. Masingmasing kelompok 5 ekor tikus. Tikus dipelihara dalam kandang individual dengan suhu dijaga $\pm 25^{\circ} \mathrm{C}$. Pemberian pakan standar AIN - 93M dan minum dilakukan secara ad libitum. Setelah proses adaptasi selama 7 hari, 4 kelompok tikus diinduksi alloxan dosis $80 \mathrm{mg} / \mathrm{kgBB}$ tikus (17). Tiga hari kemudian, kadar glukosa darah tikus diukur menggunakan metode Glucose Oxidase Phenol 4Aminoantipirin (GOD-PAP). Tikus dianggap mengalami diabetes apabila kadar glukosa darah mencapai $>126 \mathrm{mg} / \mathrm{dl}$. Perlakuan jumlah hewan coba dalam penelitian ini telah melalui uji ethical clearence di depan komisi Etik Penelitian LSIH Universitas Brawijaya dan dinyatakan laik etik. Perlakuan diberikan menggunakan rancangan tersarang (nested design) yang menggunakan dua faktor yaitu perlakuan (faktor A) dan waktu (faktor B). Tikus dibagi dalam lima kelompok perlakuan yaitu (A1) tikus normal dengan perlakuan aquades (kontrol negatif); (A2) tikus diabetes tanpa pemberian suplemen ekstrak cincau hitam (kontrol positif), (A3): tikus diabetes dengan perlakuan obat glibenklamid dosis $0,135 \mathrm{mg} / 200 \mathrm{gBB}$ tikus; (A4) tikus diabetes yang diberi suplemen ekstrak cincau hitam dosis 7,2mg/200gBB tikus (dosis 1); dan (A5) tikus diabetes yang diberi suplemen ekstrak cincau hitam dosis $21,6 \mathrm{mg} / 200 \mathrm{gBB}$ tikus (dosis 2). Pemeriksaan kadar gula darah dilakukan dalam lima waktu yaitu minggu ke $0,1,2$, 3, dan 4 .

Perhitungan dosis yang digunakan untuk tikus dengan berat $200 \mathrm{~g}$ ditentukan dari dosis pada manusia dengan berat $70 \mathrm{~kg}$, dengan konversi 0,018 kali (18). Dengan asumsi berat 1 kapsul suplemen $400 \mathrm{mg}$, dan dosis pada manusia untuk pencegahan adalah 3 kali pemberian 1 kapsul perhari diperoleh dosis 1 untuk tikus adalah $400 \mathrm{mg} x$ $0,018=7,2 \mathrm{mg} / 200 \mathrm{gBB}$ tikus/hari dan dosis 2 adalah $7,2 \mathrm{mg} / 200 \mathrm{gBB}$ tikus $\times 3=21,6 \mathrm{mg} / 200 \mathrm{gBB} /$ hari. Perlakuan ekstrak cincau hitam diberikan dengan disonde sebanyak $2 \mathrm{ml}$ setiap hari selama 4 minggu.

Untuk pembuatan serbuk ekstrak, simplisia cincau hitam dihancurkan dalam blender kering dengan kecepatan sedang selama 2 menit kemudian di timbang. Proses ekstraksi simplisia dilakukan menggunakan pelarut etanol dengan perbandingan 1:20 dengan metode maserasi suhu $27^{\circ} \mathrm{C}$, selama $3 \times 24$ jam (14). Penyaringan ekstrak cincau hitam dengan menggunakan kertas saring. Pemekatan dilakukan dengan menggunakan rotary evaporator (suhu $50^{\circ} \mathrm{C}$ selama 7 jam). Proses pemekatan bertujuan untuk memperkecil volume ekstrak sehingga diperoleh ekstrak pekat $(20 \%(\mathrm{v} / \mathrm{v})$ sehingga mudah untuk dikeringkan menjadi produk bubuk dan untuk keperluan analisa. Ekstrak cincau hitam yang sudah mengalami proses pemekatan hingga $20 \%$ volume awal, selanjutnya ditambahkan dengan dekstrin $5 \%$ (b/v). Pengeringan menggunakan oven bersuhu $50^{\circ} \mathrm{C}$ selama 48 jam sehingga akan diperoleh serbuk kering ekstrak cincau hitam atau produk suplemen cincau hitam.

Kadar senyawa total fenol dalam sampel ditentukan dengan pereaksi folin-ciocalteau (15). Sebanyak $1 \mathrm{mg}$ sampel dimasukkan ke dalam tabung reaksi dan dilarutkan ke dalam $7 \mathrm{ml}$ aquades. Selanjutnya secara berturut-turut ditambahkan 0,5ml Folin Ciocalteau 50\% (v/v) dan 
didiamkan selama 5 menit kemudian ditambahkan $1 \mathrm{ml}$ larutan $\mathrm{Na} 2 \mathrm{CO} 35 \%$ (b/v). Sampel kemudian di-vortex dan didiamkan selama 1 jam dalam ruang tertutup (gelap), kemudian dimasukkan ke dalam kuvet dan diukur menggunakan spektrofotometer dengan $=725 \mathrm{~nm}$. Blanko dilakukan dengan mengganti sampel dengan aquades. Total fenol diukur berdasarkan nilai absorbansi dan persamaan regresi linier menggunakan kurva standar asam kafeat. Hasil yang diperoleh berupa satuan ppm.

Aktivitas antioksidan $\left(\mathrm{IC}_{50}\right)$ diukur dengan metode DPPH (16). Sebanyak $10 \mathrm{mg}$ sampel ditimbang kemudian ditambah aquades sebanyak $100 \mathrm{ml}$ dan dikocok hingga homogen. Dibuat seri pengenceran $20,40,60,80$, dan 100 ppm menggunakan etanol $96 \%$ sebanyak $10 \mathrm{ml}$. Larutan yang sudah diencerkan diambil $4 \mathrm{ml}$ dan ditambah 0,2 mM larutan 1,1-diphenyl-2-pycrilhidrazil (DPPH) dalam etanol $96 \%$ sebanyak $1 \mathrm{ml}$. Sesudah sampel didiamkan selama 30 menit, kemudian diukur absorbansinya dengan $=517 \mathrm{~nm}$. Kapasitas antioksidan diukur dengan formula: (abs. kontrol-abs. sampel)/abs kontrol_x 100\%. Nilai konsentrasi sampel dari masing-masing larutan serta hambatan radikal bebas (\% inhibisi) diplot masing-masing pada sumbu $x$ dan y pada persamaan regresi linear. Nilai $I_{50}$ menyatakan bahwa konsentrasi larutan yang dibutuhkan untuk mereduksi radikal bebas DPPH sebesar $50 \%$.

Kadar glukosa darah ditetapkan secara enzimatik dengan pereaksi glucose oxidase phenol 4-aminoantipyrine (GOD PAP) dari Diasys. Analisa glukosa darah pada tikus dilakukan setelah tikus dipuasakan selama 12 jam. Setelah 12 jam dipuasakan, darah tikus diambil secara retro melalui sinus orbitalis menggunakan pipa kapiler hematokrit. Setelah itu, darah di sentrifuge selama 15 menit dengan kecepatan 4000rpm dan diambil $10 \mu \mathrm{l}$ sampel. Sampel kemudian ditambahkan dengan $1000 \mu l$ reagen untuk selanjutnya divortex dan diinkubasi pada suhu $20-25^{\circ} \mathrm{C}$ selama 20 menit. Tahapan selanjutnya adalah membaca absorbansi sampel menggunakan spektro-fotometer dengan panjang gelombang 500 nm. Kadar glukosa darah dihitung menggunakan rumus: (Abs. sampel/Abs. Standar) x konsentrasi standar (100mg/dl).

Pemeriksaan gambaran histologi dilakukan untuk mengetahui perbedaan gambaran struktur jaringan pankreas pada masing-masing perlakuan. Pemeriksaan gambaran histologi jaringan pankreas menggunakan metode pewarnaan Hematoxylin-Eosin (HE). Pewarnaan pada preparat diawali dengan tahap deparafinisasi, kemudian rehidrasi, pewarnaan dalam hematoxylin, pewarnaan dalam eosin, dehidrasi, clearing (penjernihan), dan mounting (perekatan). Gambaran histologi sel $\beta$ pankreas diamati menggunakan mikroskop Olympus BX51 dengan perbesaran 400 x.Data dianalisa dengan analisis ragam dengan menggunakan Analysis of
Varian (ANOVA) dengan selang kepercayaan 0,05\%, untuk mengetahui apakah terdapat pengaruh pada tiap perlakuan. Apabila hasil uji menunjukkan terdapat beda sangat nyata pada interaksi kedua perlakuan, maka dilanjutkan dengan uji lanjut Duncan's Multiple Range Test (DMRT) dengan selang kepercayaan 0,05\%.

\section{HASIL}

Inhibition concentration $\left(\mathrm{IC}_{50}\right)$ dapat didefinisikan sebagai konsentrasi larutan sampel yang akan menyebabkan reduksi terhadap aktivitas DPPH sebesar 50\%. Semakin kecil nilai IC ${ }_{50}$ menunjukkan aktivitas antioksidan semakin tinggi. Suatu senyawa dikatakan sebagai antioksidan yang sangat kuat apabila nilai $I_{50}$ kurang dari 50ppm, kuat apabila nilai $I C_{50} 50-100 p p m$, sedang apabila nilai $I C_{50}$ 100-150ppm, dan lemah bila nilai IC ${ }_{50}$ antara 150-200ppm (19). Nilai $I C_{50}$ yang dihasilkan pada produk suplemen cincau hitam ini berkisar antara 50 - 100ppm, menunjukkan antioksidan kuat (Tabel 1).

Tabel 1. Hasil analisis ekstrak cincau hitam

\begin{tabular}{lr}
\hline \multicolumn{1}{c}{ Analisis } & \multicolumn{1}{c}{ Hasil } \\
\hline Kada Air (\%) & $6,02 \pm 0,23$ \\
Total Fenol (ppm) & $100,33 \pm 14,61$ \\
IC $_{50}(\mathbf{p p m})$ & $69,04 \pm 2,89$ \\
\hline
\end{tabular}

Hasil pengamatan selama 4 minggu pada kadar gula darah tikus diabetes yang diberi perlakuan suplemen cincau hitam dengan dosis 1 maupun dosis 2 dan obat glibenklamid setiap minggunya terjadi penurunan kadar gula darah. Sebaliknya pada kontrol positif (tikus diabet tanpa perlakuan cincau hitam) terjadi kenaikan setiap minggunya (Tabel 2). Hasil uji statistik ragam (ANOVA), menunjukkan bahwa kelompok perlakuan suplemen cincau hitam berbeda nyata $(\alpha=0,05)$ dengan kelompok perlakuan kontrol positif. Kelompok perlakuan suplemen dosis 2 tidak berbeda nyata dengan kelompok perlakuan obat glibenklamid. Penurunan kadar gula darah selama perlakuan 4 minggu pada dosis 2 mencapai 53,65\%. Temuan ini menunjukkan bahwa pemberian ekstrak cincau hitam dosis 2 dapat menurunkan kadar gula darah pada tikus model diabetes dengan efek yang sama dengan pemberian glibenklamid.

Pengamatan histologi pankreas pada tikus percobaan dilakukan untuk mengetahui pengaruh perlakuan suplemen cincau hitam dan obat glibenklamid terhadap pemulihan fungsi pankreas akibat induksi aloksan. Hasil pengamatan hispatologi pankreas tikus dapat dilihat pada Gambar 1. Pada kelompok tikus normal atau kontrol negatif (Gambar 1a) tampak tidak terjadi nekrosis dan

Tabel 2. Perubahan kadar glukosa darah tikus Wistar diabetes pada semua perlakuan selama 4 minggu

\begin{tabular}{lcccccc}
\hline Perlakuan & $\begin{array}{c}\text { Minggu 0 } \\
(\mathbf{m g} / \mathbf{d L})\end{array}$ & $\begin{array}{c}\text { Minggu 1 } \\
(\mathbf{m g} / \mathbf{d L})\end{array}$ & $\begin{array}{c}\text { Minggu 2 } \\
(\mathbf{m g} / \mathbf{d L})\end{array}$ & $\begin{array}{c}\text { Minggu 3 } \\
\text { (mg/dL) }\end{array}$ & $\begin{array}{c}\text { Minggu 4 } \\
\text { (mg/dL) }\end{array}$ & $\begin{array}{c}\text { Penurunan } \\
\text { KGD (\%) }\end{array}$ \\
\hline Kontrol Negatif & $75,79 \pm 0,70$ & $76,79 \pm 1,02$ & $79,26 \pm 1,04$ & $79,85 \pm 0,97$ & $80,51 \pm 0,82$ & $-6,241 \pm 1,396$ \\
Kontrol Positif & $218,31 \pm 9,97$ & $222,38 \pm 8,62 \mathrm{a}$ & $229,09 \pm 5,37 \mathrm{a}$ & $228,31 \pm 5,76 \mathrm{a}$ & $230,72 \pm 5,27 \mathrm{a}$ & $-5,768 \pm 2,520 \mathrm{a}$ \\
Dosis 1 & $212,91 \pm 13,89$ & $170,71 \pm 3,94 \mathrm{~b}$ & $156,33 \pm 4,42 \mathrm{~b}$ & $139,04 \pm 3,28 \mathrm{~b}$ & $116,86 \pm 3,86 \mathrm{~b}$ & $44,990 \pm 2,855 \mathrm{~b}$ \\
Dosis 2 & $229,07 \pm 46,39$ & $167,06 \pm 3,39 \mathrm{~b}$ & $151,75 \pm 3,14 \mathrm{~b}$ & $125,69 \pm 2,70 \mathrm{~b}$ & $103,49 \pm 2,75 \mathrm{c}$ & $53,659 \pm 7,740 \mathrm{c}$ \\
Glibenklamid & $210,00 \pm 11,01$ & $146,03 \pm 3,01 \mathrm{c}$ & $136,06 \pm 6,36 \mathrm{c}$ & $110,02 \pm 4,75 \mathrm{c}$ & $95,08 \pm 2,98 \mathrm{c}$ & $54,613 \pm 3,071 \mathrm{c}$ \\
\hline
\end{tabular}

Keterangan: $a b c^{*}$ notasi yang berbeda menunjukkan perbedaan signifikan 
terlihat inti sel (berwarna ungu pada preparat) sangat padat serta tidak terdapat sel-sel yang mengalami edema (pembengkakan). Hal ini mengindikasikan bahwa islet Langerhans dalam keadaan normal (tidak terjadi kerusakan). Pada Gambar 1c dan 1d memperlihatkan pulau Langerhans secara mikroskopis terdapat perbedaan efek yang ditimbulkan akibat perlakuan yang diberikan. Gambaran histologi pankreas kelompok diabetes dengan perlakuan suplemen cincau hitam menunjukan kondisi pankreas dan pulau Langerhans sudah mendekati normal. $\mathrm{Hal}$ ini menunjukan terjadinya regenerasi sel di dalam pulau Langerhans dan berkurangnya ruang kosong akibat nekrosis sel.
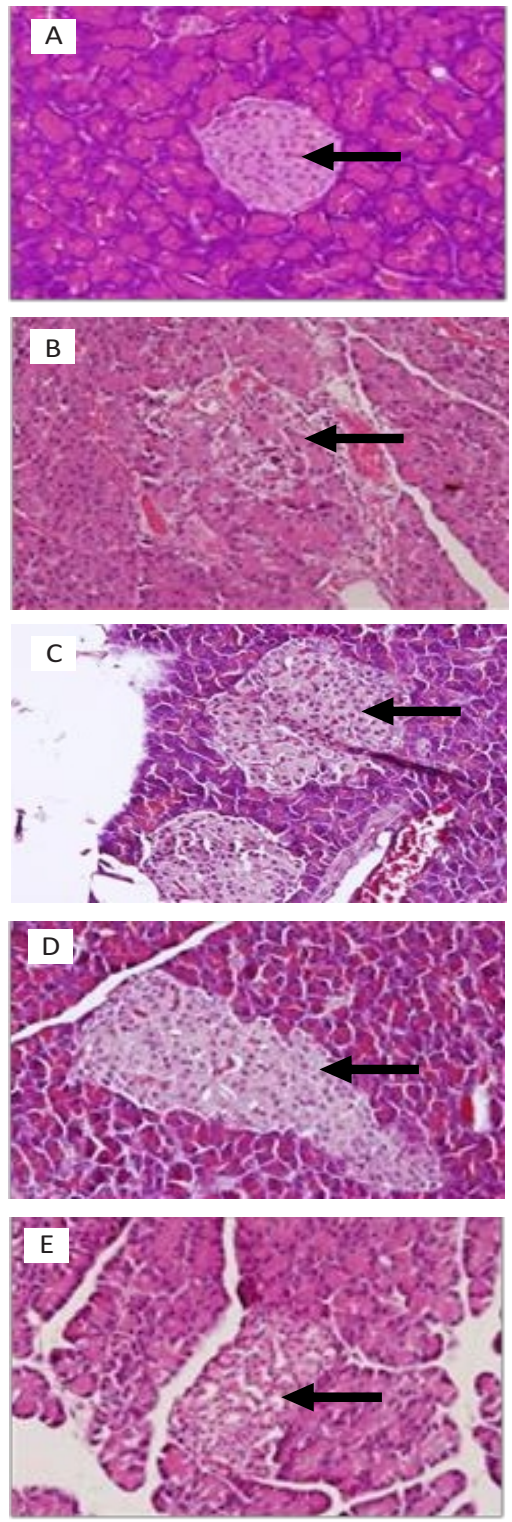

Gambar 1. Pengamatan Histologi Pankreas pada tikus percobaan

Keterangan: (Tanda anak panah menunjukkan sel $\beta$ pankreas)

a. Histologi pankreas tikus perlakuan kontrol negatif (400x)

b. Histologi pankreas tikus perlakuan kontrol positif $(400 x)$ tikus diabetes

c. Histologi pankreas tikus perlakuan suplemen cincau hitam dosis $7,2 \mathrm{mg} / 200 \mathrm{gBB}(400 \mathrm{x})$

d. Histologi pangkreas tikus perlakuan suplemen cincau hitam dosis $21,6 \mathrm{mg} / 200 \mathrm{gBB}(400 \mathrm{x})$

e. Histopatologi pankreas tikus perlakuan obat glibenklamid dosis $0,135 \mathrm{mg} / 200 \mathrm{gBB}(400 \mathrm{x})$

\section{DISKUSI}

Ekstrak cincau hitam mengandung senyawa bioaktif seperti komponen polifenol, flavonoid, dan saponin, senyawa-senyawa ini dikenal sebagai antioksidan alami karena memiliki properti penangkap radikal bebas yang menghasilkan aktifitas antioksidan (8). Dalam proses pembuatan suplemen cincau hitam ditambahkan dekstrin yang bertujuan untuk mencegah kerusakan oksidatif senyawa bioaktif karena panas selama proses pengeringan atau bersifat sebagai mikro-enkapsulasi (20). Suplemen cincau hitam pada penelitian ini mempunyai aktifitas antioksidan (IC $\mathrm{C}_{50}$ ) sebesar 69,041ppm, tergolong aktifitas antioksidan yang kuat yaitu antara 50-100ppm (19).

Diabetes melitus dapat disebabkan oleh beberapa faktor diantaranya faktor genetik, infeksi, faktor nutrisi, zat diabetogenik, dan radikal bebas (stres oksidatif). Senyawa alloxan merupakan salah satu zat diabetogenik yang bersifat toksik, terutama terhadap sel beta pankreas dan apabila diberikan kepada hewan coba seperti tikus maka dapat menyebabkan tubuh tidak bisa menghasilkan insulin sehingga menyebabkan kadar glukosa darah meningkat (terjadi keadaan hiperglikemia). Kondisi hiperglikemia dapat memperparah kerusakan sel beta pangkreas (21).

Pada peneitian ini pemberian ekstrak cincau hitam dosis 2 (21,6mg/200gBB) dapat memberikan efek hipoglikemik yang sama dengan pemberian glibenklamid. Suplemen cincau hitam yang terbuat dari ekstrak etanol cincau hitam mengandung senyawa bioaktif polifenol, flavonoid, saponin dan tannin sehingga dapat bersifat antioksidan (12). Flavonoid diduga dapat meningkatkan aktivitas antioksidan dengan meningkatkan enzim antioksidan seluler seperti SOD, katalase, glutation peroksidase yang berperan dalam mencegah kerusakan DNA sel $\beta$ pankreas yang diinduksi alloxan (22). Flavonoid bersifat protektif terhadap kerusakan sel $\beta$ sebagai penghasil insulin serta dapat meningkatkan sensitivitas insulin (23). Mekanisme lain adalah kemampuan flavonoid dalam menghambat GLUT 2 mukosa usus sehingga dapat menurunkan absorbsi glukosa $(23,24)$. Selain itu, flavonoid dapat menghambat fosfodiesterase sehingga dapat menyebabkan sekresi insulin oleh sel beta pankreas (24). Peran polifenol sebagai antioksidan diduga mampu melindungi sel beta pankreas dari efek toksik radikal bebas yang diproduksi dibawah kondisi hiperglikemiakronis (25). Obat glibenklamid merupakan obat derivat sulfonilurea. Mekanisme kerja obat golongan sulfonilurea dengan cara menstimulasi penglepasan insulin yang tersimpan (stored insulin) dan meningkatkan sekresi insulin akibat rangsangan glukosa termasuk menurunkan kadar glukagon dalam serum (22).

Pankreas tikus diabetes yang diinduksi alloxan pada pengamatan histopatologis menunjukkan terjadi nekrosis dan degenerasi sel yang cukup parah, dengan banyak terdapat ruang kosong pada pulau Langerhans. Terjadinya nekrosis dan degenerasi sel pada kelompok diabetes disebabkan oleh adanya induksi alloxan pada tubuh tikus yang merupakan radikal bebas yang dapat merusak biomakromolekul seperti lipid, fosfolipid, dan karbohidrat yang merupakan komponen dinding sel, serta DNA yang berada dalam inti sel. Aktivitas radikal bebas tersebut akan menyebabkan dinding sel menjadi rusak dan mengalami degenerasi hingga nekrosis dengan sitoplasma yang pucat dan inti sel yang rusak (26). Kerusakan sel beta pankreas ditandai dengan perubahan progresif pada pulau Langerhans, termasuk perubahan deplesi atau 
berkurangnya sekretori granul insulin pada sel beta pankreas, lepasnya pertautan sel pulau Langerhans, dan pergantian sel-sel eksokrin oleh jaringan ikat, fibrosis (27).

Pemberian ekstrak cincau hitam pada tikus model diabetes pada penelitian ini mampu menunjukkan perbaikan histopatologis sel pulau Langerhans pankreas. Kondisi pulau Langerhans semakin membaik dan bentuk sel mulai utuh diduga karena adanya senyawa bioaktif yaitu flavonoid dan polifenol (23). Senyawa bioaktif tersebut dapat bertindak sebagai antioksidan. Aktivitas antioksidan yang dimiliki oleh suplemen cincau hitam tergolong tinggi $\left(I C_{50}=69,04 \mathrm{ppm}\right)$, sehingga mampu memperbaiki sel beta pankreas yang rusak. Antioksidan terlibat dalam proses perbaikan sel yang rusak yang diakibatkan oleh adanya radikal bebas. Adanya antioksidan berfungsi sebagai agen penurun dan menurunkan oksidator sebelum merusak sel sehingga kerusakan sel dapat dikurangi (28). Gambaran histologi pankreas sesudah pemberikan ekstrak cincau hitam dosis $21,6 \mathrm{mg} / 200 \mathrm{gBB}$ lebih baik jika dibandingkan dengan dosis dosis $7,2 \mathrm{mg} / 200 \mathrm{gBB}$ menunjukkan sel-sel didalam pulau Langerhans mulai rapat mendekati ciri-ciri pankreas tikus normal. Hal ini dikarenakan dengan meningkatnya dosis maka jumlah senyawa bioktif dalam suplemen juga meningkat.

Gambaran histologi pankreas pada kelompok perlakuan

\section{DAFTAR PUSTAKA}

1. Wild S, Roglic A, Green A, Sicree R, and King H. Global Prevalence of Diabetes Estimates for the Year 2000 and Projections for 2030. Diabetes Care. 2004; 27(5): 1047-1053.

2. World Health Organization. Country and Regional Data: World. (Online) 2009. diabetes/facts/ world.html [diakses tanggal 10 September 2013].

3. Evans JL, Goldfine ID, Maddux BA, and Grodsky GM. Oxidative Stress and Stress-Activated Signaling Pathways: A Unifying Hypothesis of Type 2 Diabetes. Endocrine Reviews. 2002; 23(5): 599-622.

4. Oprescu Al, Bikopoulos G, Naassan A, et al. Free Fatty Acid-Induced Reduction in Glucose-Stimulated Insulin Secretion: Evidence for a Role of Oxidative Stress In Vitro and In Vivo. Diabetes Journal. 2007; 56(12): 2927-2937.

5. Tony $\mathrm{H}$ dan Suharto B. Insulin, Glukagon, dan Antidiabetik Oral. Di dalam: Ganiswara SG. Farmakologi dan Terapi Edisi 4. Jakarta: Gaya Baru; 2005; hal. 467-481.

6. Baynes JW and Thorpe SR. Role of Oxidative Stress in Diabetic Complications. A New Perspective on an Old Paradigm. Diabetes. 1999; 48(1): 1-9.

7. Hung CY and Yen GC. Extraction and Identification of Antioxidative Components of Hsian- Tsao (Mesona Procumbens Hemsl). Lebensimittle-Wissenschaft und-Technologie. 2001; 34(5): 306-311.

8. Widyaningsih TD. Potential Black Cincau (Mesona Palustris BL) as Functional Food Ingredients is Imunomodulator. Seminar of Proceeding of the Local Food, LIPI. Yogyakarta, 2010.

9. Yen GC, Hung YL, and Hsieh CL. Protective Effect of Extracts of Mesona Procumbens Hemsl on DNA diabetes dengan obat glibenklamid $0,135 \mathrm{mg} / 200 \mathrm{gBB}$ masih menunjukan adanya nekrosis sel yang ditandai dengan adanya ruang kosong di dalam pulau Langerhans, meskipun sel-sel di dalamnya sudah utuh. Pemberian glibenklamid sebagai obat tidak menunjukan perubahan morfologi pankreas yang signifikan seperti pada perlakuan kelompok diabetes dengan perlakuan suplemen cincau hitam. Hal ini dikarenakan pemberian glibenklamid hanya untuk memperbaiki fungsi sel yang memproduksi insulin tetapi tidak memperbaiki bentuk ataupun morfologi pulau Langerhans yang mengandung sel-sel beta pankreas (29). Obat hipoglikemik oral kemungkinan efektif untuk kontrol glikemik setidaknya pada tahap awal diabetes, namun menjadi tidak sepenuhnya efektif dalam pencegahan kerusakan organ yang diperantarai ROS (30).

Penelitian ini membuktikan bahwa serbuk ekstrak cincau hitam dengan $\mathrm{IC}_{50}=69,041 \pm 2,89 \mathrm{ppm}$, tergolong bersifat antioksidan kuat dan bersifat hipoglikemik karena dapat menurunkan kadar gula darah tikus diabetes yang diinduksi alloxan. Pemberian ekstrak cincau hitam dosis $21,6 \mathrm{mg} / 200 \mathrm{BB}$ tikus selama 4 minggu mempunyai efek hipoglikemik yang sama dengan glibenklamid. Dibandingkan dengan glibenklamid, ekstrak cincau hitam juga dapat mempengaruhi histologi pulau langerhans sel pankreas dan memperbaiki kerusakan secara kualitatif pada tikus diabetes yang diinduksi aloksan.

Damage in Human Lymphocytes Exposed to Hydrogen Peroxide and UV Irradiation. Food and Chemical Toxicology. 2000; 38(9): 747-754.

10. Yen GC, Duh PD, and Hung YL. Contibutions of Major Components to the Antimutagenic Effect of Hsiantsao (Mesona procumbens Hemsl). Journal of Agricultural and Food Chemistry. 2001; 49(10): 5000-5004.

11. Yeh CT, Huang $\mathrm{WH}$, and Yen GC. Antihypertensive Effects of Hsian-Tsao and Its Active Compound In Spontaneously Hypertensive Rats. The Journal of Nutritional Biochemistry. 2009; 20 (11): 866-875.

12. Widyaningsih TD, Sukardiman, Djoko AP, and Darmanto W. Immunomodulatory Effects of the Water Extract of Black Cincau (Mesona Palustris BL) Against Interferon Gamma Expression, ImmunoSurveillance Activation and Apoptosis on Benzo (A) Pyrene-Induced Fibrosarcoma Carcinogenesis in Mice. Journal of Technology and Food Industry. 2012; 23(1): 29-35.

13. Widyaningsih TD. Olahan Cincau Hitam. Surabaya: Trubus Agrisarana; 2007.

14. Hung CY and Yen GC. Antioxidant Activity of Phenolic Compounds Isolated rom Mesona Procumbens Hemsl. Journal of Agricultural and Food Chemistry. 2002; 50(10): 2993-2997.

15. Andarwulan N and Shetty K. Stimulation of Novel Phenolic Metabolite, Epoxy-Psuedoisoeugenol-(2 Methylbutyrate) [EPB], in Trans-formed Anise (Pimpinella Anisum L.) Root Cultures by Fish Protein Hydro-lysates. Journal of Food Biotechnology. 2000; 14: $1-20$.

16. Hatano $T$, Edamatsu $R$, Hiramitsu $M$, et al. Effect of the Interaction of Tannins with Co-Existing Substances. VI. Effect of Tannins and Related 
Polyphenols on Superoxide Anion Radical and on 1,1-Diphenyl-2-Picrylhidrazil Radical. The Journal Chemical and Pharmaceutical Bulletin. 1989; 37: 2016-2021.

17. Rachmadani AD dan Estiasih T. Beras Analog Berbasis Umbi Garut (Maranta Arundinaceae L) dan Alginat sebagai Pangan Berkhasiat Obat (Medicinal Foods) yang Diujikan pada Tikus Hiperglikemik. [Skripsi]. Universitas Brawijaya, Malang. 2010.

18. Kusumawati D. Bersahabat dengan Hewan Coba. Yogyakarta: Gadjah Mada University Press; 2004.

19. Molyneux P. The Use of the Stable Free Radical Diphenyl Picrylhydrazyl (DPPH) for Estimating Antioxidant Activity. Songklanakarin Journal of Science and Technology. 2004; 26(2): 211-219.

20. Nurdin MH. Pengembangan Produk Minuman Fungsional Teh Instan Berbahan Cincau Hitam (Mesona Palustris BL) dengan Metode Pengeringan Hampa Udara. [Skripsi]. Universitas Brawijaya, Malang. 2012.

21. Aronson D. Hyperglycemia and the Pathobiology Of Diabetic Complications. Advances in Cardiology. 2008, 45: 1-16.

22. Mycek MJ, Harvey RA, dan Champe PC. Insulin dan Obat-Obat Hipoglikemik Oral. Edisi 2. Jakarta: Widya Medika. 2001.

23. Jian Song, Oran K, Shenglin C, Rushad D, Peter E, Jae $\mathrm{BP}$, and Mark L. Membrane Transport Structure Function and Biogenesis: Flavonoid Inhibition of SVCT1 And GLUT2, Intestinal Transporters for Vitamin $C$ and Glucose. The Journal of Biological Chemistry. 2002; 277(18): 15252-15260.
24. Kwon O, Eck P, Chen S, et al. Inhibition of Intestinal Glucose Transporter GLUT2 by Flavonoids. The Journal of the Federation of American Societies for Experimental Biology, 2007; 5(21): 336-377.

25. Bunting K, Wang J, and Shannan MF. Control of Interleukin-2-gene Transcription: A Paradigm for Inducible, Tissue Specific Gene Expressions. Vitamins and Hormones. 2006;74:105-45.

26. Lenzen S. The Mechanisms of Alloxan and Streptozotocin-Induced Diabetes. Diabetologia. 2008; 51(2): 216-226.

27. Diani AR, Sawada G, Wyse B, Murray FT, and Khan M. Pioglitazone Preserves Pancreatic Islet Structure and Insulin Secretory Function in Three Murine Models of Type 2 Diabetes. The American Journal of PhysiologyEndocrinology and Metabolism. 2004; 286(1): 116122.

28. Yamada S, Komatsu M, Sato Y, et al. Time Dependent Stimulation of Insulin Exocytosis by 3',5'-Cyclic Adenosine Monophosphate in the Rat Islet Beta-Cell. Endocrinology. 2002; 143(11): 4203-4209,

29. Suherman dan Suharti K. Insulin dan Antidiabetik Oral. Di dalam: Setiabudy GR, Nafrialdi, Elysabeth (Eds). Farmakologi dan Terapi. Jakarta: Departemen Farmakologi dan Terapeutik Fakultas Kedokteran Universitas Indonesia; 2007.

30. Cook MN, Girman CJ, Stein PP, Alexander CM, and Holman RR. Glycemic Control Continues to Deteriorate After Sulfonylureas are Added to Metformin among Patients with Type 2 Diabetes. Diabetes Care. 2005; 28(5): 995-1000. 